\title{
FEATURE
}

\section{Shall We Get Rid of the Reference Desk?}

Dennis B. Miles

Dennis B. Miles is Assistant Professor, Technical Access \& Public Services Librarian, Southeastern Oklahoma State University

Reference \& User Services Quarterly, vol. 52, no. 4, pp. 320-333

(c) 2013 American Library Association. All rights reserved.

Permission granted to reproduce for nonprofit, educational use.
This study examines the prevalence of offering reference services from the reference desk in 119 academic libraries at universities offering master's level programs. Survey results found that 66.4 percent of libraries still used the reference desk to offer reference services, and 77.21 percent of libraries use a professional librarian at the reference desk all or some of the time.

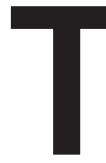
raditional reference services involve a professional librarian sitting at a reference desk waiting for patrons to approach and when a question is asked, providing assistance. This model of service is one that, for many librarians, is hard to give up. However, an increasing numbers of librarians claim that the reference desk is outmoded and that there are better ways to provide reference service.

The spark that began the process of offering assistance to patrons was ignited when Samuel Swett Green of the Worcester Free Public Library presented his paper "The Desirableness of Establishing Personal Intercourse and Relations Between Librarians and Readers in Popular Libraries" at the American Library Association Conference in 1876. After his article appeared in Library Journal in November of that year, there was a gradual change in the role of the librarian from custodial to service-oriented. ${ }^{1}$

Just when the reference desk came to be the point of contact for help from a librarian is not known. However, in an 1886 report of the St. Louis Public Library, the term desk was used as the place where the library assistant answered questions, and by the early 1890s the term information desk was being used. ${ }^{2}$ Once reference librarians began to use the desk as the place to do their work in serving people, the model stuck. Few questioned the assumption that the reference desk was the very center of reference service until the 1980s.

\section{LITERATURE REVIEW}

Many librarians have complained that reference service from the desk is an inefficient method in providing service to patrons and needs to be drastically changed or eliminated. In 1986, Barbara Ford was one of the first to suggest the elimination of the reference desk. Ford questioned both the efficiency and effectiveness of reference service provided from the reference desk and challenged the idea of the reference desk as the center of reference service. ${ }^{3}$ Keith Ewing and Robert Hauptman, 
David W. Lewis, Jerry D, Campbell, Gabriela Sonntag, and Felicia Palsson have all advocated for the elimination of the reference desk. ${ }^{4}$ Steven Bell has been an active voice in calling for eliminating the reference desk. He reiterated the main problems of the reference desk and said that the reference desk is only a symbol of reference service, not the service itself. He then concluded it is time to eliminate the reference desk and adopt new models. ${ }^{5}$

What are the problems with traditional reference service? Karen Summerhill pointed out that reference librarians have an inefficient service model, one that is designed for "emergency' style services in a non-emergency situation."' Summerhill argued that the consultation services that professional librarians should give should be offered by appointment, like lawyers, doctors, teachers, and professors do, not in the emergency style that is common at the reference desk. ${ }^{7}$ Ann Lipow felt that when a patron needs help from the reference librarian, it means that the tools that are in place to help the patron-the catalog, the signage—have failed. ${ }^{8}$ Aaron Schmidt said that putting librarians behind a desk is "unfriendly" to patrons and makes it easy for librarians to ignore what is going on around them. ${ }^{9}$ Other problems cited with traditional reference service include

- librarians wasting time waiting for reference questions to answer; ${ }^{10}$

- most of the questions asked are of the kind that any trained student can answer, and even the complicated ones that librarians traditionally answer can be answered by students with proper training; ${ }^{11}$

- and the high cost of professional librarians manning the reference desk. ${ }^{12}$

However, the biggest problem with traditional reference service has to do not with the model, but with changes in the world around the reference librarian. The library used to be the repository of human knowledge and was the only place to go to find information. The reference librarian was the guide to this world of information. However, with the rise of the Internet as a tool to find information, patrons no longer needed to go to the library to find information. They could now find information for themselves from their homes for the first time. Tycokson concluded that this was the technological event that really changed the playing field for the traditional reference model. ${ }^{13}$

According to the ALA statistics, academic libraries as a whole experienced a 50 percent decline in reference transactions in fourteen years (1994-2008). ${ }^{14}$ The Internet and other changes in technology also led to changes in how students seek information when doing research; they go to the Internet first rather than to a reference librarian. ${ }^{15}$ These changes in technology and in information seeking have had an impact on the reference desk as a point of service.

Are there any arguments to support providing reference service from the desk? One reason is human contact value, the personal, one-to-one interaction that goes on at the reference desk. Gorman supported this view:
It borders on the fatuous to propose that technology can be employed to provide a satisfactory alternative to the nuances of the interaction between librarian and user, knowledge of the whole range of recorded knowledge and information, and the subtleties of information and knowledge seeking. . . . Technology can enhance but will never supplant human-to-human reference service. . . . We must maintain the vital human-tohuman component that typifies reference service across our history. This is an age in which human values are under strain; human contact and sympathy become more prized as they become rarer. ${ }^{16}$

Sobel indicated in her study of students at Auraria Library at the University of Colorado-Denver that 69 percent of first year college students preferred face-to-face reference options over virtual reference options. ${ }^{17}$ Kilzer said that the real product of providing reference services at the reference desk is the attention that librarians can give to the students. ${ }^{18}$ Nolen did a comparison of pro- and anti-desk articles over twenty-five years and concluded that the two sides share a central component of human contact value. ${ }^{19}$ Human contact value is the main argument for keeping service at the reference desk.

The many problems with having reference services offered by professional librarians from a desk could convince librarians to abandon that model. Numerous examples in the literature show librarians adopting new models of reference service, such as roving reference, ${ }^{20}$ outreach reference, ${ }^{21}$ consultation reference, ${ }^{22}$ and combining service points. ${ }^{23}$ How do librarians feel about getting rid of the reference desk and going to a different model? Are libraries actually abandoning the reference desk? Dawson found in science, engineering, and medical libraries at fifty-three colleges and universities in New Jersey that traditional reference service from the reference desk is still the primary model for offering reference services. ${ }^{24} \mathrm{~A}$ survey by Brunsting conducted in 2006 of 261 libraries from medium-sized fouryear colleges and universities (3,036 to 10,187 FTE) asked which of seven reference staffing patterns they used. She found that when the three models that involved librarians only were totaled (one librarian at a single service point, more than one librarian at a single service point, two librarians at two service points), the three models totaled 62.9 percent. Brunsting also said that 43.8 percent of the respondents said that they used the one librarian-one service point model..$^{25}$

\section{METHODOLOGY}

Prompted by Steven Bell's article "Who Needs a Reference Desk," in Library Issues in the summer of 2007, ${ }^{26}$ the author at Southeastern Oklahoma State University (hereafter referred to as Southeastern) conducted a study of questions recorded at the reference desk, which revealed that questions had declined almost every year at Southeastern since 2000. To find out if other libraries were also experiencing declines in their reference questions, the author surveyed librarians on several library 


\section{FEATURE}

Table 1. Number of Full-Time Professional Librarians

\begin{tabular}{lccccccccc}
\hline \multicolumn{7}{c}{ 1. How many full-time professional librarians are at your institution? } \\
$\mathbf{N = 1 1 9}$ & 0 & $1-2$ & $3-4$ & $5-6$ & $7-8$ & $9-10$ & $11-12$ & $13-14$ & $14 \leq$ \\
\hline Number & 0 & 14 & 34 & 33 & 16 & 7 & 11 & 1 \\
Percent & 0.00 & 11.76 & 28.6 & 27.7 & 13.45 & 5.88 & 9.24 & 0.84
\end{tabular}

mailing lists. The survey asked librarians how they felt about abandoning the traditional reference model and whether or not they had actually abandoned that model. The author sent a modified survey out in early 2009 and modified it again and sent for the third time in 2010. All the surveys indicated a wide acceptance of using the traditional model. However, problems with the design of one question of the 2010 survey resulted in inconclusive results and prevented use of the survey. ${ }^{27}$ For that reason, the author sent a fourth survey out in the fall of 2011. This time, the author limited the target population to the colleges and universities with the same Carnegie Classification as Southeastern in order to focus the survey on a particular class of academic libraries that are the most like Southeastern. The Carnegie Classification has been a major method used to classify the different kinds of US higher education institutions for the past four decades. The Carnegie Commission on Higher Education developed a classification of colleges and universities to support its program of research and policy analysis back in 1970. The Carnegie Classification was originally published in 1973 and subsequently updated in 1976, 1987, 1994, 2000, 2005 , and 2010 to reflect changes among colleges and universities. ${ }^{28}$ Carnegie 2010 Basic Classification 19 has 186 institutions. This classification (the one that Southeastern is in) has a description of colleges and universities that have medium-sized master's degree programs. This represents 4 percent of all US colleges and universities. The average size of these institutions is 4,233 students. ${ }^{29}$ The author went to the Carnegie Classification website and used the list of these 186 institutions at that site. All websites of these institution's libraries were visited in August-October 2011. The author visited the staff directory of each library, selected a professional librarian, and sent the link to the survey by email. Librarians were selected if they had the term reference in their title in the staff directory of the institution. However, in some instances there was not a librarian with the term reference in their title in the staff directory, so in those cases any librarian was selected. In some cases, a staff directory could not be located, and so any email contact point with the library was selected. There were 20 colleges and universities that could not be used because no library could be identified on the website, such as DeVry University or the University of Phoenix. There were an additional 4 universities in Puerto Rico that had webpages that were in Spanish, so they were not included. This reduced the total to 162 schools.

The librarians were sent the survey several times in October-November 2011. There was no provision in the survey to identify the person who answered the survey, making it anonymous. After receiving a low number of responses from these 162 colleges and universities, the 128 colleges and universities in Carnegie Classification 20 were added, which is the classification for institutions that have smaller masters degree programs. After weeding out those institutions where no librarian could be identified or contacted, 92 librarians received the survey. This class of colleges has an average enrollment of 2,893 students. ${ }^{30}$ In the end, surveys were sent to a total of 254 librarians in the two Carnegie classifications, out of which 119 responded.

The survey was voluntary, which meant that the survey respondent could choose not to answer any question or any part of any question. In some of the questions, respondents exercised that right. The number of respondents for each question varies, from 12 to 119 . Percentages in each question are based on the number of librarians that actually answered the question, omitting those that did not respond. There was also space for comments in most of the questions, providing further valuable information.

\section{RESULTS}

The first survey question asks how many full-time librarians work at the institution of the respondent. As shown in table 1 , a majority of the libraries surveyed have either 3 to 4 librarians (28.60 percent) on staff or 5 to 6 librarians on staff ( 27.70 percent). Southeastern has six librarians on staff, so it is in this range. Most of the libraries ( 81.51 percent) have less than 9 librarians on staff, which is a reflection on the smaller size of the institutions that the libraries serve. Only 2.50 percent have more than 14 librarians. All libraries surveyed have at least one professional librarian on staff.

The second question pertains to the number of library staff providing reference services. As shown in table 2, more than half (54.31 percent) of the libraries surveyed have four or fewer librarians that provide reference services, and almost 90 percent have eight or less. Most libraries surveyed (36.21 percent) have 3 to 4 librarians that provide reference services. All libraries have at least one professional librarian who is involved in reference services, which further supports the value that librarians place on reference. Most of the libraries (95.24 percent) have 2 or fewer part-time professional librarians that provide reference services. As the number of full-time professional librarians that provide reference services goes up, the number of part-time professional librarians goes down. A large number of libraries (47.62 percent) have no part-time professional librarians who provide reference service. However, a large number of libraries surveyed (56) did not respond to this question. It is likely that they did not answer this part of the 
Table 2. Number of Library Staff Providing Reference Services

\begin{tabular}{lcccccccccc}
\hline & \multicolumn{7}{c}{ 2. How many people on your staff provide reference services? } \\
& 0 & $1-2$ & $3-4$ & $5-6$ & $7-8$ & $9-10$ & $11-12$ & $13-14$ & $14 \leq$ \\
\hline Full-time professional librarians & 0 & 21 & 42 & 27 & 14 & 4 & 2 & 3 \\
\hline percent $(\boldsymbol{N}=\mathbf{1 1 6})$ & 0.00 & 18.10 & 36.21 & 23.28 & 12.07 & 3.45 & 1.72 & 2.59 & 2.59 \\
Part-time professional librarians & 30 & 30 & 1 & 1 & 1 & 0 & 0 & 0 & 0 \\
\hline percent $(\mathbf{N}=\mathbf{6 3})$ & 47.62 & 47.62 & 1.59 & 1.59 & 1.59 & 0.00 & 0.00 & 0.00 & 0.00 \\
Nonprofessional staff & 15 & 32 & 19 & 6 & 5 & 3 & 1 & 1 \\
percent $(\mathbf{N}=\mathbf{8 8})$ & 17.05 & 36.36 & 21.59 & 6.82 & 5.68 & 3.41 & 1.14 & 1.14 & 6.82 \\
\hline
\end{tabular}

Table 3. Number of Years of Service as a Professional Librarian

3. How many years have you been a professional librarian? $(N=119)$

\begin{tabular}{cccccccccc} 
& 0 & $<1$ & $1-2$ & $4-6$ & $7-10$ & $11-15$ & $16-20$ & $20<$ \\
\hline number & 1 & 7 & 8 & 21 & 12 & 18 & 12 & 40 \\
percent & 0.84 & 5.88 & 6.72 & 17.65 & 10.08 & 15.13 & 10.08 & 33.61 \\
\hline
\end{tabular}

3a. How many years have you been a professional librarian? $(N=119)$

\begin{tabular}{lccc} 
& 0 & $<7$ & $7 \leq$ \\
\hline number & 1 & 36 & 82 \\
percent & 0.80 & 30.25 & 68.91
\end{tabular}

question because they have no part-time professional librarians who provide reference services. If this is the case, the percentage of libraries that have no part-time professional librarians who provide reference services jumps to 72.27 percent.

Many libraries use nonprofessional staff to assist at the reference desk. In the survey, 82.95 percent of the libraries that answered the question have at least one nonprofessional staff that provides reference services. However, 31 did not answer this part of the question, and it is not known why they did not answer.

A comparison of question 1 with question 2 leads to some interesting findings. For example, 58.82 percent of the libraries surveyed use all or nearly all of their professional librarians in reference work. It is probable that this is a reflection on the smaller student body size of the institution that each library serves. In larger universities, there are probably more librarians that are performing nonreference duties. On the opposite end, all libraries surveyed have at least one professional librarian involved in reference work. Other staffing figures further reinforce the idea that reference is a service that is provided mainly by reference librarians with assistance from nonprofessionals: 77.14 percent of the libraries that use all or nearly all of their librarians for reference service have less than seven librarians on their staff. This shows that when there aren't as many professional librarians on the staff, the first priority is reference duty, and the figures above suggest that the place to do that reference is still at the reference desk. This reflects a sense that the institutions surveyed value the idea of a "professional" librarian that has been trained with the knowledge of the value of resources and expertise to assist patrons.
The third question asks how many years that the person answering the survey has been a professional librarian. All 119 respondents answered this question, and the results indicated that respondents tend to be more experienced, with 86.55 percent having four or more years of experience, and 68.91 percent having more than seven or more years experience, as is shown in table 3. There were 33.61 percent that had twenty or more years of experience, and there was 1 respondent who was not a professional librarian. A possible reason for this was a nonintentional bias in favor of the more experienced during the selection process. By focusing on selecting respondents by the word reference in their title, many librarians chosen for the survey were the head of reference and thus tended to have more experience.

\section{PROFESSIONAL LIBRARIANS AT THE REFERENCE DESK}

The fourth question is the heart of the survey. The respondents were asked if their library currently provides reference services from a traditional reference desk, and 66.4 percent said that they do. This is surprising given the volume of declarations in the literature over many years about the reference desk being obsolete or inefficient. For those that are among the 33.6 percent that indicated that they do not provide reference services from a traditional reference desk, the respondent comments to this question indicate that some are sharing the desk with IT staff, others have combined the reference and circulation desk into one service point, and others have 


\section{FEATURE}

Table 4. Libraries Providing Reference Service from the Reference Desk

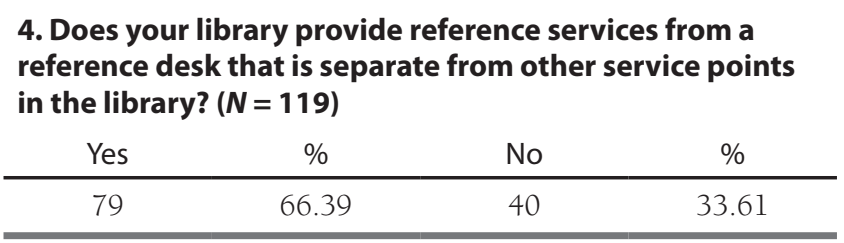

librarians on call in their offices.

Why do the librarians at these libraries still offer service from the reference desk? One librarian commented in the survey, "The reference desk provides a wealth of teachable moments that librarians should be trained to recognize." Another said, "The reference desk staffed by professional reference librarians is still needed. For reference librarians to even consider not doing this is irresponsible, selfish and lazy." Another librarian pointed out the need to be visible: "Because it's what I was born to do and it's what I love to do. Sitting in your office hiding and writing papers no one will ever read is called being a writer, not a librarian." Another librarian pointed out the commitment of the library director to reference: "Even our Director takes two shifts per week at the desk because of his commitment for all librarians to stay in touch with the needs of students." Finally, a respondent said, "We still take pride in the fact a student can come down to the library at any time (yes, granted when we are on the desk, but we are on call when not on the desk) and get professional help with their research needs." ${ }^{31}$ Clearly many librarians still have strong feelings about the kind of service that they can offer from the traditional reference desk.

What makes librarians feel this way? As mentioned in the comments above, librarians take pride in what they do just as people in other professions. Teachers take pride in being good at instilling knowledge in student's minds, and doctors take pride in saving lives. It is a matter of loving what you do and doing it well. As already mentioned, when libraries have fewer professional librarians on staff, they tend to put those librarians in reference work first. It is also a matter of taking responsibility for providing a visible presence in the library, in order to provide face-to-face assistance to students. The ALA standard Guidelines for Behavioral Performance of Reference and Information Service Providers says that being visible to the students is important to librarians, reinforcing this responsibility. ${ }^{32}$ Librarians are trained to serve, to teach, and to assist. As the survey indicates, most feel that they can provide this important service best at the reference desk.

\section{INCREASE OR DECREASE OF REFERENCE QUESTIONS}

At this point in the survey the respondents who answered yes to question 4 were taken to five additional questions that pertained to the reference desk. If they answered no, they skipped over those questions. So the following five questions pertain to only the 79 respondents who answered yes to question 4 .

The first question in this section of the survey asks if the number of questions asked at the reference desk has been increasing or declining in the past two years. The author asked this question because Southeastern had experienced a decline in reference questions, and it was important to know if other libraries had experienced the same decline. The time period was limited to two years to make the question easier to answer, and 71 librarians responded to this question. In the survey, the number of libraries that experienced an increase in the number of questions was slightly more (23.94 percent) than those that experienced a decrease in questions (22.54 percent), and 53.52 percent experienced little change in the number of questions, which means that at more than half of the libraries, the number of reference questions is not declining. Taken together, there are 77.46 percent of the responding libraries where reference questions are not declining at the reference desk.

It is surprising that there is a large percentage of libraries in the survey that experienced an increase or little change in the number of reference questions in the past two years. This contradicts the ALA statistics cited earlier. It is possible that if a comparison of more than two years was made, the decline indicated from 1994 to 2008 in the ALA statistics would still show. It is apparent that declines in reference questions are not universal in all libraries.

There are many reasons why some libraries are experiencing increases in reference questions. What those reasons are can be gleaned from the comments given by the participants who said that they experienced an increase in the number of reference questions in the last two years. These comments include remodeling the building, visiting classrooms for ten-minute library sessions that also serve as marketing opportunities, communicating with faculty about assignments, teaching bibliographic instruction classes to students, and making the area around the reference desk student friendly. Any attempt to connect with students and to show that they are interested in helping them appears to be helpful in having the students ask questions at the reference desk.

\section{WHY THERE ARE DECLINES IN REFERENCE TRANSACTIONS}

Question 6 asks those libraries who have experienced a decline in reference questions why they think that they did. This question was addressed only to the 16 libraries that answered that the number of reference questions asked at the desk had gone down in the past two years. However, since it was possible for any of the other 79 librarians to answer this question, other librarians besides the 16 that the question was designed to target answered the question. This question allowed the librarians to select as many reasons given as they felt applied to their situation. As table 5 shows, the top reason given by librarians 
Table 5. Why Have There Been Declines in Reference Questions

Question 6. If you have been experiencing a decline in the number of reference questions at the reference desk, why do you think this is so? (Please check all that apply) $(N=23)$

\begin{tabular}{|c|c|c|}
\hline & number & percent \\
\hline Students go to the Internet for all their answers and think they don't need librarians & 18 & 78.26 \\
\hline Students are embarrassed to ask for help & 16 & 69.57 \\
\hline Students think that they can do research without help & 14 & 60.87 \\
\hline Students now ask for help from a librarian electronically (chat, email, texting) instead of at the desk & 13 & 56.52 \\
\hline Students are given assignments that do not require help from librarians & 8 & 34.78 \\
\hline Students don't come to the library because they are taking classes online & 8 & 34.78 \\
\hline Students would rather ask a nonlibrarian for help (library student worker) & 5 & 21.74 \\
\hline Students would rather ask a fellow student for help & 4 & 17.39 \\
\hline Students do not know who the librarians are & 3 & 13.04 \\
\hline Librarians at the reference desk seem unapproachable (grumpy, disinterested, preoccupied in their own work) & 3 & 13.04 \\
\hline Students know how to search already & 0 & 0.00 \\
\hline
\end{tabular}

Table 6. Reference Desk Staffing

Question 7. How does your library staff the reference desk? $(N=68)$

\begin{tabular}{lcc} 
& number & percent \\
\hline Only professional librarians staff the reference desk all of the time & 28 & 41.18 \\
$\begin{array}{l}\text { Professional librarians staff the reference desk some hours and nonprofessional staff or students staff the desk } \\
\text { other hours }\end{array}$ & 33 & 48.53 \\
A professional librarian shares the desk with a nonlibrarian at the same time & 3 \\
A nonprofessional librarian staffs the reference desk all of the time and refer harder questions to librarians & 4.41
\end{tabular}

for why they experienced a decline in reference questions was that students don't need the librarian because they go to the Internet for all their answers. Other top reasons given by the librarians are students are embarrassed to ask for help (69.57 percent), students think that they can do research without help (60.87 percent), and students ask for help electronically (56.52 percent). Reasons for declines in reference statistics that few librarians choose are students would rather ask a fellow student for help (17.39 percent), librarians at the reference desk seem unapproachable (13.04 percent), and students do not know who the librarians are (13.04 percent). Other reasons mentioned in the comments of this question include (1) students feel that they are bothering the librarian since most librarians do other work while at the desk and (2) this generation of students does not think to ask for help.

\section{DIFFERENT KINDS OF REFERENCE DESK MODELS}

Question 2 of the survey asks the number of full-time librarians, part-time librarians and nonprofessional staff that provide reference services, whether they are at the desk or not. Question 7 asks a subset of that number, the library staff that are used at the reference desk, how the library staffs the reference desk. Of the 68 librarians who answered question 7 (94.20 percent) indicate that professional librarians are still at the reference desk all or part of the time. As table 6 shows, the greatest number of librarians indicated that they alternate desk coverage with nonprofessionals (48.53 percent), followed by professional librarians staff the reference desk all the time (41.18 percent). Very few (5.88 percent) staff the desk exclusively with nonlibrarians, while 4.41 percent have a librarian and a nonlibrarian share the reference desk at the same time. This data shows that for most libraries in the study who indicated that they provide reference services at a reference desk, the reference librarian is still very much involved. Librarians have been trained to offer face-to-face assistance, and assistance is at the core of what a librarian is and has been for over one hundred years. With the Internet has come an easy way for patrons to answer their own questions, causing some to think that the day of providing reference service from the reference desk is nearly over. However, the results of this survey have supported the claim that the reference desk is not dead, and even though reference services have expanded into the online world, the core of reference service at this time is still at the reference desk. 


\section{FEATURE}

Table 7. Future Reference Desk Staffing

Question 8. How do you want to staff the reference desk in the future? $(N=69)$

\begin{tabular}{|c|c|c|c|}
\hline & number & percent & $\begin{array}{l}\text { increase/ } \\
\text { decrease }\end{array}$ \\
\hline Only professional librarians staff the reference desk all of the time & 31 & 44.93 & $(+) 3.75$ \\
\hline $\begin{array}{l}\text { Professional librarians staff the reference desk some hours and nonprofessional staff or students } \\
\text { staff the desk other hours }\end{array}$ & 25 & 36.23 & $(-) 12.3$ \\
\hline A professional librarian shares the desk with a nonlibrarian at the same time & 6 & 8.7 & $(+) 4.29$ \\
\hline $\begin{array}{l}\text { A nonprofessional librarian staffs the reference desk all of the time and refers harder questions to } \\
\text { librarians }\end{array}$ & 7 & 10.14 & $(+) 4.26$ \\
\hline
\end{tabular}

\section{FUTURE STAFFING OF THE REFERENCE DESK}

When the librarians were asked how they wanted to staff the reference desk in the future, 31 (almost 45 percent) of those that responded wanted to have only professional librarians staff the desk all of the time, which is 3.75 percent more than those libraries that currently have only reference librarians on the desk. When all reference models where a librarian is involved with the reference desk are added up, 89.86 percent of the respondents said that the librarian needs to spend some time at the reference desk. However, 10 chose not to answer this question and so the percentages are based on the 69 librarians that did answer this question. Clearly this data indicates again that librarians feel that they need to be at the reference desk answering questions.

\section{WHY REFERENCE SERVICE IS PROVIDED FROM THE REFERENCE DESK}

Why do libraries still provide reference services from the reference desk? Question 9 gives several options that the respondents could pick from. The question allowed the 70 respondents to this question to choose as many reasons listed in the survey question that they felt described their situation. The number one reason that librarians in the survey indicated for still providing reference services is the human contact, face-to-face help that they can give students (see table 8). Comments from some of the librarians further explain why librarians feel this way: "Our institution is small and very high-touch. Students expect professional, capable, informed librarians to help them with their research questions. We staff our reference desk almost all of our open hours."

Another pointed out the professional nature of reference work by saying, "We are unionized and answering reference questions is faculty work. Paraprofessionals answer directional questions and work at low use times only." Finally, one librarian pointed out the necessity of human contact value by saying, "Even though this university has been a laptop u for 12 years, digital reference has not taken off. Personal touch is expected and desired by students. We do have a separate desk for technology issues (virus removal, locked computer accounts, installing print paths, etc). We did experiment with using library techs and even students at Reference, but moved away from that."

The number two reason indicated by the librarians as a reason to stay at the reference desk was that they answer questions better than nonprofessional staff can. This is a view that gets at the librarian's training and expertise and that they are better equipped to answer questions, and for these reasons they still feel that they need to be at the reference desk; 80 percent of the librarians in this survey feel that way. This feeling is also reflected in question 8, where more librarians wanted librarians to staff the reference desk exclusively in the future than the present. Also 51.43 percent feel that librarians can answer more questions than nonprofessional/ student workers can. Other reasons included librarians need to stay current on student needs/assignments (77.14 percent), librarians need to be where students expect them to be (64.29 percent), having a librarian at the reference desk promotes student questions (51.43 percent), librarians need to be at reference desk because there are still enough questions being asked (51.43 percent), administration commitment to this type of service (41.43 percent), the physical layout of the building makes this kind of service the best for our library (35.71 percent), tradition ( 28.57 percent), students expect service delivered in this way (27.14 percent), not enough staff (14.29 percent), and resistance of librarians to changing the way reference services are provided (11.43 percent). Many of these reasons why librarians feel that they need to be at the reference desk stem from the one-on-one, human interaction that they can provide by being at the reference desk. Librarians feel that they can provide reference services better than anyone else.

\section{OTHER WAYS TO PROVIDE REFERENCE SERVICE}

In response to concerns about the traditional reference desk model, libraries have tried new ways to offer reference service besides the reference desk. Many libraries began offering roving reference. In this model, the librarian got out from behind the reference desk and engaged the patron at the point of need..$^{33}$ As shown in table 9, more that 47 percent of the 70 librarians who answered this question in the survey 
Table 8. Why Use the Reference Desk?

Question 9. If you continue to have professional librarians providing reference services at the reference desk, why are you doing that? (select all that apply) $(N=70)$

\begin{tabular}{|c|c|c|}
\hline & number & percent \\
\hline Librarians need to provide face-to-face help for students (human contact value) & 62 & 88.57 \\
\hline Librarians can answer questions better than nonprofessional/student workers & 56 & 80.00 \\
\hline Librarians need to stay current on student needs/assignments & 54 & 77.14 \\
\hline Librarians need to be where students expect them to be (central point of access) & 45 & 64.29 \\
\hline Having a librarian at the reference desk promotes student questions & 36 & 51.43 \\
\hline Librarians need to be at the reference desk because there are still enough questions being asked & 36 & 51.43 \\
\hline Librarians can answer more questions than nonprofessional/student workers & 36 & 51.43 \\
\hline Administration commitment to this type of service & 29 & 41.43 \\
\hline The physical layout of the building makes this kind of service the best for our library & 25 & 35.71 \\
\hline Tradition & 20 & 28.57 \\
\hline Students expect service delivered in this way & 19 & 27.14 \\
\hline Not enough staff & 10 & 14.29 \\
\hline Resistance of librarians to changing the way reference services are provided & 8 & 11.43 \\
\hline
\end{tabular}

Table 9. Ways Libraries Provide Reference Services in Addition to the Reference Desk

Question 10. What ways does your library provide reference services, not including the reference desk? (also not including electronic reference services) $(N=70)$

\begin{tabular}{lcc} 
& $\begin{array}{c}\text { Provide in addition to reference } \\
\text { services at the reference desk }\end{array}$ & $\begin{array}{c}\text { Provide in place of reference services } \\
\text { at the reference desk }\end{array}$ \\
\hline $\begin{array}{l}\text { Librarians provide reference services in their } \\
\text { offices (consultation model) }\end{array}$ & $61(87.14 \%)$ & $2(2.86 \%)$ \\
$\begin{array}{l}\text { Librarians rove the library, answering questions } \\
\text { at the point of need in the stacks, computer labs, } \\
\text { information commons, anywhere else that there } \\
\text { are students in the library needing help }\end{array}$ & $33(47.14 \%)$ & $1(1.43 \%)$ \\
$\begin{array}{l}\text { Combine the reference and circulation desks } \\
\text { into one service point, with a nonprofessional } \\
\text { answering easy questions, referring hard } \\
\text { questions to a professional librarian }\end{array}$ & $10(14.29 \%)$ & $2(2.86 \%)$ \\
\hline
\end{tabular}

provide this type of reference in addition to the service that they provide at the desk. Almost no librarians (1.43 percent) provide this type of service in place of the service that they provide at the desk.

Another way of providing reference service is to combine service points into one, such as offering circulation and reference services from one desk. ${ }^{34}$ In 14.29 percent of the libraries who answered this question, combining service points is provided in addition to reference service from a reference desk, and a very low percentage, 2.86 percent, provide this service in place of a reference desk. Poor question design may have played a role in the responses to this question. Are 14 percent of the libraries surveyed really providing reference service from another service point (such as the circulation desk) and a reference desk? It is easy to see how some librarians might have misunderstood this question. However, it is possible that at some libraries there are two reference service points. What is clear is that most libraries have not combined service points into one, again supporting the reference desk as the preferred model.

A third way to offer reference services is through consulting with students in the librarian's office. ${ }^{35}$ Consultation services are offered in addition to the reference desk by over 87 percent of the libraries surveyed (see table 9). This kind of service is more in line with what many librarians feel should be the kind of reference service that professional librarians offer-answering difficult questions and teaching patrons how to find and use resources. However, only 2.86 percent of the libraries offer this kind of service in place of traditional reference service from the reference desk. Again, this type of reference service is supplemental to the main service at the reference desk. 


\section{FEATURE}

Table 10. Reasons why librarians have been moved off the reference desk

Question 11. If you have moved professional librarians off of the reference desk, why did you do that? (select all that apply) $(N=12)$

Librarians need time to provide instruction to classes

number percent

Not enough questions that require a librarian's expertise

$10 \quad 83.33$

Not enough staff

$6 \quad 50.00$

Librarians need time to answer virtual reference questions (chat, texting, e-mail)

541.67

Librarians need time to provide reference services at other locations on campus

$3 \quad 25.00$

Librarians are too busy with other jobs to help students

325.00

Librarians need time to provide roving reference services

$2 \quad 16.67$

(going to the patrons at the points of need, in the stacks, computer labs)

Nonprofessionals can provide just as good reference service as librarians do at less cost

18.33

Students disliked accessing reference services from the desk

Mandated from administration

1

8.33

Table 11. Librarian Agreement to the Statement: The Reference Desk is the Best Place to Answer Students' Questions

Question 12. The reference desk is the best place for professional librarians to answer students' questions $(N=112)$

\begin{tabular}{ccccc} 
strongly agree & agree & neutral & disagree & strongly disagree \\
\hline $17(15.18 \%)$ & $33(29.46 \%)$ & $41(36.61 \%)$ & $15(13.39 \%)$ & $6(5.36 \%)$ \\
\hline
\end{tabular}

These three different ways of providing service are used in addition to the regular reference services from the desk in many libraries, but very few use these services in place of the reference desk. Also 49 of the respondents skipped this question, again suggesting that they do not use any of these models. This suggests the power that the traditional reference model still has for librarians.

\section{REASONS TO MOVE AWAY FROM THE REFERENCE DESK}

In question 4, 33.6 percent of the librarians indicated that they have shifted staff from providing reference services at the desk. Why did these libraries decide to move staff from the reference desk? Only 12 librarians answered this question. Again, the librarians chose from a list of options (see table 10). Among those 12 who responded, 83.33 percent indicated that librarians need time to provide instruction to classes, 50 percent indicated that not enough questions came in requiring a librarian's expertise, and 41.67 percent indicated that there were not enough staff. Other answers included focus on virtual reference questions (25 percent), focus on providing reference services at other locations on campus ( 25 percent), librarians are too busy with other jobs to help students (16.67 percent), focus on providing roving reference services (8.33 percent), cost savings from using nonprofessionals at the desk (8.33 percent), student dislike for accessing reference services from the desk (8.33 percent), and mandates from administration (8.33 percent). This question was available to all 119 in the survey to answer, and 107 chose not to answer, probably because it did not apply to many of them because they are still providing reference services from the reference desk.

\section{IS THE REFERENCE DESK THE BEST PLACE TO OFFER REFERENCE SERVICES?}

Question 12 asks the librarians whether they felt the reference desk is the best place to offer reference services. As table 11 indicates, 44.64 percent of the 112 who answered this question strongly agreed or agreed with the statement that the reference desk is the best place for professional librarians to answer students' questions, but a substantial number (36 percent) were neutral on this question. Why they were neutral is unclear, but the comments made by some of those who responded may clarify the question. Some of those that chose neutral did so because they felt that the reference desk is just one of many places where reference questions can be answered. Others said that it depends on the type of question or the assignment, need, or student comfort level with asking questions at the desk. Others said that electronic resources have changed the usefulness of the reference desk. Here are additional reasons:

- Our service desk is still heavily used, more so than other 
Table 12. Librarian Response to Statement: Librarians Should Answer only Questions that Make Use of their Training and Expertise

Question 13. Librarians should only answer questions that require their professional expertise and leave other, simpler questions to nonprofessionals (simpler questions are defined as directional questions, questions regarding logins to computers or databases, fixing paper jams, printer problems, library hours, etc) $(N=111)$

\begin{tabular}{ccccc} 
strongly agree & agree & neutral & disagree & strongly disagree \\
\hline 9 & 16 & 21 & 32 & 33 \\
8.11 & 14.41 & 18.92 & 28.83 & 29.73 \\
\hline
\end{tabular}

avenues of contact with a reference librarian.

- It would depend on the size of the library and school.

- Many reference questions are e-posted or phoned in.

- A balance of both would seem best. Some students like to see me by appointment and in private. Others are fine with the desk. One can have too many hours in either place as well as too few.

- It's a passive approach-there are things about it that work-things about it that don't

What is clear from the survey is that only about 19 percent of the librarians surveyed feel that the reference desk is not the best place for professional librarians to answer student's questions, indicating still strong support for the reference desk.

\section{SHOULD LIBRARIANS LIMIT THEMSELVES TO QUESTIONS THAT MAKE USE OF THEIR TRAINING AND EXPERTISE?}

Question 13 targeted librarian's attitudes about the kinds of questions that librarians should answer. Many librarians feel that they should only be answering questions that make use of their training and expertise. ${ }^{36}$ What is surprising is that 58.56 percent of the 111 who answered this question disagreed with this statement, as is shown in table 12 , and almost 30 percent strongly disagreed. Why they disagreed is given in the comments below:

- It's about relationship building! AND sometimes simple questions lead to bigger ones. This attitude is a shot in the proverbial foot.

- Any contact can build confidence in students to ask questions and give librarians the opportunity to "promote" the library resources.

- This attitude helps no one.

- While I do agree that more in-depth, detailed research questions should be answered only by librarians, I think that both nonprofessionals and professional librarians can answer the simpler questions. It should not be beneath a librarian to answer those questions.

- Service is our mission, so if we can assist with nonresearch questions, we do.

- Refusing to fill paper/ help with printing/ etc... places a wall between you and your patron.
- Student's first question may be tip of iceberg-reference librarian trained to conduct reference interview and get to real or deeper questions.

- Librarians certainly can answer these questions, but these questions can distract from other value added services a library might offer such as information literacy \& faculty liaison programs.

- Professional librarians need to be open to every sort of question at all times. That's just plain good customer service.

- If I'm asked "Where's the bathroom?" I will not send a patron to another desk for that answer. It makes us appear arrogant and defeats any type of service orientation. At my university, librarians are faculty so I advise undeclared majors. I solve their problems, for example, if their financial aid is messed up-I talk with the registrar to get it straightened out. I don't just send the student off to the registrar. I have a lot of loyalty from my students and get high rating from them as an advisor. This seems a direct parallel to reference service.

- Librarians should answer ALL questions, but when it gets busy, easier questions should be handed off to nonprofessionals.

These statements indicate strong support for the idea of service to patrons, no matter how trivial or small the questions, that has been in place in libraries for many years. This is surprising in light of ALA definitions of reference which clearly state that reference transactions are not about locations, equipment, nor policy statements. ${ }^{37}$

\section{PROVIDING REFERENCE SERVICES TO THOSE NOT IN THE LIBRARY}

The strong service orientation of librarians prompts them to provide help to patrons wherever they might be. As changes in technology made it possible to communicate more easily with students not in the library, many libraries began to use these new ways of communication to provide reference services. Question 14 was asked to find out what other ways libraries are providing reference services to users not in the library, and 114 of the librarians answered this question. With the telephone being a technology that has been around for many years and is used by most of the population, it would be expected that most libraries would offer this kind 


\section{FEATURE}

Table 13. Providing Services to Students not in the Library

Question 14. How does your library provide reference services for students not in the library? $(N=114)$

\begin{tabular}{lrc} 
& number & percent \\
\hline Librarians provide reference service through email, either on the reference desk or elsewhere & 109 & 95.61 \\
Librarians provide reference by telephone & 108 & 94.74 \\
Librarians provide reference service through chat, either on the reference desk or elsewhere & 70 & 31.4 \\
Librarians provide reference services through mobile technology (cell phone) with text messaging & 28.95 \\
Librarians provide reference service through Facebook, either on the reference desk or elsewhere & 26.32 \\
Librarians located in other places on campus (student center, other buildings) setting up a remote information & 30 \\
station & 7.02 \\
Librarians provide reference by Skype & 4.39 \\
Our library does not provide service for those outside of the library & 0
\end{tabular}

Table 13a. Providing Services to Students not in the Library by Number of Services Provided

How does your library provide reference services for students not in the library? $(N=114)$

\begin{tabular}{|c|c|c|}
\hline & number & percent \\
\hline Telephone and email & 105 & 92.11 \\
\hline Telephone, email, and chat & 64 & 55.26 \\
\hline Telephone, email, chat, and text messaging & 27 & 23.68 \\
\hline Telephone, email, chat, text messaging, and Facebook & 12 & 10.53 \\
\hline
\end{tabular}

Table 13b. Providing Services to Students not in the Library for those Libraries that Provide Services from the Reference Desk by Number of Services Provided

\begin{tabular}{lr} 
Services that libraries offer to those not in the library who also offer services from the reference desk (N= 74) & number \\
& percent \\
\hline Telephone and email & 92.11 \\
Telephone, email, and chat & 59.26 \\
Telephone, email, chat, and text messaging & 40 \\
Telephone, email, chat, text messaging, and Facebook & 16 \\
\hline
\end{tabular}

of reference service, and 94.74 percent of respondents indicated that they provide services by telephone. However, just slightly more (95.61 percent) of the librarians said that they provide reference services by email. Over half (61.4 percent) report that they offer reference services by chat, and about a third (34.21 percent) provide reference services through text messaging. These are newer technologies, and it was expected that their use in reference would be lower. Facebook is a popular social networking site, and about a quarter of the respondents (26.32 percent) provide reference services through Facebook. Skype is used by only 4.39 percent of the libraries surveyed. Only 7.02 percent provide reference services outside the library building, but where outside the library is not indicated; how they offered that service includes visiting classrooms, traveling to a branch campus, acting as a liaison to the faculty, having a reference librarian available in the campus course management system, and using Twitter.
What is clear is that all libraries surveyed offer some kind of service to students outside of the library.

As shown in table 13a, there are 105 (92.11 percent) libraries that offer both telephone and email service; 63 libraries (55.26 percent) offer telephone, email, and chat reference; and 27 (23.68 percent) who offer telephone, email, chat, and text messaging service. Finally, there are 12 libraries (10.53 percent) that offer reference service to those not in the library in five ways: telephone, email, chat, text messaging, and Facebook. None of the libraries indicated that they use all seven methods to contact those outside of the library.

Libraries that still use the reference desk also provide reference services to students outside the library. As shown in table 13b, 93.24 percent of the libraries that provide reference services from the reference desk also provide telephone and email reference service; over half (54.05 percent) of the libraries that use the reference desk also offer telephone, email, and 
chat reference service; 21.62 percent of the libraries that provide reference services from the reference desk also provide email, telephone, chat, and text messaging reference service; 10.81 percent of the libraries that provide reference services from the reference desk also provide email, telephone, chat, text messaging, and Facebook reference service. There are only 8 (7.02 percent) libraries that provide reference services outside of the library, and 7 of those 8 ( 87.5 percent) also provide reference services from the reference desk.

\section{CONCLUSION}

It is clear that most librarians at mid-size colleges and universities responding to the survey still see the reference desk as the focal point for reference service. Even with all the discussion in the literature about the problems with traditional reference services and how this model of service should be done away with, most libraries continue with some variation of reference service in this way. The librarians indicated that the face-to-face interaction with patrons is the most important reason why librarians still want to offer service from the desk. This shows that the commitment, desire, and feelings of responsibility are still there among the librarians surveyed.

Also in the libraries surveyed, most have not seen a decrease in the number of reference questions asked at the reference desk, indicating that, for libraries that are experiencing a decline in the number of questions from the reference desk, this should not be used as the reason for taking the librarians off the reference desk without looking at some of the reasons why there has been an increase in the number of reference questions in other libraries.

In the libraries surveyed, other reference service methods, such as roving reference and consultation services, are being offered in addition to the service from the reference desk, but few libraries offer these kinds of reference services in place of the reference desk, indicating that the service from the desk is the foundation from which the other services spring.

Librarians at these institutions seem committed to service at the reference desk in the future, with slightly more saying that they want to offer reference services by librarians from the reference desk in the future than those that indicated that they currently provide reference services at the desk. There also seems to be great commitment to providing services to students not in the library, and what varies is how that service is offered. Most provide multiple ways that students can access a librarian from outside the library, and some provide reference options that use technology that students use all the time.

Further research is needed to determine if there is any difference in librarians' attitudes at both larger research universities and smaller colleges, or if there is a difference between public and academic libraries. Also further research is needed to see if students feel the same way the librarians do about the service that librarians offer from the reference desk, or if students feel that other models are more effective. Further research is also needed to determine why some libraries are experiencing a decline in reference questions while others are experiencing an increase.

For Southeastern Oklahoma State University, the reference model changed in the fall of 2011 from having a reference librarian on the reference desk for most hours that the library was open to having one librarian, on a rotating schedule, being on call all the time. The reason this change was made was due to providing too many services and having too many projects and not enough staff to effectively do them all. However, a few of the students complained in the annual Library Student Satisfaction Survey, conducted in April 2012, that they didn't like not having a librarian at the reference desk, so the librarians decided to put librarians back on the reference desk during the time of day that most of the reference questions were being asked.

What are the implications of this survey for academic libraries with smaller to medium-sized master's degree programs? Libraries may need to assess the services that they are offering to students and place reference service at a high level of need. Some services may need to be done away with to be able to continue to provide needed reference service. Libraries will need to provide reference services in a variety of ways, with reference desk service by professional librarians being the foundation of that service. What will vary somewhat is the location of the reference desk, the size of the library staff, the amount of time the professional librarians spend at the desk, and the percentage of professional librarians at an institution that offer reference service. What seems clear is that the reference desk is not going to disappear anytime soon.

\section{References}

1. S. Rothstein, The Development of Reference Services through Academic traditions, Public Library Practice and Special Librarianship (Chicago: Association of College and Reference Libraries, 1955), ACRL Monographs Number 14, 6-21.

2. F. Crunden, "Report on Aids and Guides, August '83 to June '85," Library Journal (Milwaukee Conference Number) 10: 310, as found in S. Rothstein, "The Development of the Concept of Reference Service in American Libraries, 1850-1900," The Library Quarterly 23(1): 1-15.

3. Barbara J. Ford, "Reference Beyond (and Without) the Reference Desk" College \& Research Libraries 47, no. 5 (September 1986): 492-94.

4. Keith Ewing and Robert Hauptman, "Is Traditional Reference Service Obsolete?" Journal of Academic Librarianship 21 no. 1 (1995) 3-6; David W Lewis, "Traditional Reference Is Dead, Now Let's Move on to Important Questions," Journal of Academic Librarianship 21 no. 1 (1995) 10-12; Jerry. D Campell, "Shaking the Conceptual Foundations of Reference: A Perspective," Reference Services Review 20, no. 4 (1992): 31, 33-35; Jerry. D Campbell, "Still Shaking the Conceptual Foundations of Reference: A Perspective," Reference Librarian 48, no. 2 (2007): 22; Gabriela Sonntag and Felicia Palsson "No Longer the Sacred Cow-No Longer a Desk: Transforming Reference Service to Meet 21st Century User Needs," Library Philosophy and Practice (2007), www .webpages.uidaho.edu/ mbolin/sonntag-palsson.htm.

5. Steven. J. Bell, "Who Needs a Reference Desk?" Library Issues: Briefings for Faculty and Administrators 27, no. 6 (July 2007): 1.

6. Karen Storin Summerhill, "The High Cost of Reference: The Need 


\section{FEATURE}

to Reassess Services and Service Delivery," The Reference Librarian no. 43 (1994): 78.

7. Ibid., 79 .

8. Ann Grodzins Lipow, "The Future of Reference: Point-of-Need Reference Service: No Longer an Afterthought," Reference Services Review 31, no. 1 (2003): 31

9. Aaron Schmidt, "Revamping Reference," Library Journal 136, no. 8 (May 1, 2011): 18.

10. Edward C. Jestes and David Laird, "A Time Study of General Reference Work in a University Library," Research in Librarianship 2 (1968): 16

11. Rao Aluri and Jeffrey W. St. Clair, "Academic Reference Librarians: An Endangered Species?" Journal of Academic Librarianship 4, no. 2 (May 1978): 82; Thelma Freides, "Current Trends in Academic Libraries," Library Trends 31, no. 3 (Winter 1983): 467; Virginia Massey-Burzio, "Reference Encounters of a Different Kind: A Symposium" Journal of Academic Librarianship 18, no 5 (1992): 277; Allison I. Faixet al., "Peer Reference Redefined: New Uses for Undergraduate Students," Reference Services Review 38, no. 1 (2010): 90, 103. This study conducted at Costal Carolina University in 2009 found that upper-level undergraduate students can provide excellent reference service with proper training and guidance from librarians. Also Debbi Dinkins and Susan M. Ryan, "Measuring Referrals: The Use of Paraprofessionals at the Reference Desk," Journal of Academic Librarianship 36, no 4. (July 2010): 283. This study at Stetson University found that the nonprofessional, with training and experience, could answer 78 percent of the reference questions without a librarian assisting him in the fall 2008 semester. By the spring 2009 semester, the number of questions answered (unaided by the librarian) by the nonprofessional that were considered reference questions rose to 95 percent.

12. S. M. Ryan, "Reference Transactions Analysis: The Cost-Effectiveness of Staffing a Traditional Academic Reference Desk," Journal of Academic Librarianship 34(5): 389-99.

13. David A. Tyckoson, "What Is the Best Model of Reference Service?" Library Trends 50, no.2 (Fall 2001): 192-93.

14. American Library Association, Academic Libraries in the United States-Statistical Trends, accessed Sept. 22, 2012, www.ala.org/ ala/research/librarystats/academic/academiclibraries.cfm. To bring the reference statistics up to date, see Tai Phan et al., Academic Libraries 2010: First Look, National Center for Education Statistics, December 2011, accessed Jan. 3, 2012, http://nces.ed.gov/ pubs2012/2012365.pdf, 6. The statistics here, on which the American Library Association statistics mentioned before were based, changed the term reference transaction to information services to individuals. The information services to individuals were down to $34,599,983$, a further 38 percent decline from the number of reference transactions in 2008. (Information services to individuals, is defined as the number of information contacts that involve the knowledge, use, recommendation, interpretation, or instruction in the use of one or more information sources by a member of the library staff.)

15. Perceptions of Libraries, 2010: Context and Community: A Report to the OCLC Membership (Dublin, OH: OCLC Online Computer Library Center, 2011), 54, accessed Jan. 29, 2011, www.oclc. org/reports/2010perceptions.htm. According to this report, 83 percent of college students choose an Internet search engine first to begin research on a topic. See also Alison J. Head and Michael B. Eisenberg, Lessons Learned: How College Students Seek Information in the Digital Age, The Project Information Literacy Progress Report, The Information School, University of Washington, December 1, 2009, http://projectinfolit.org/pdfs/PIL_Fall2009_ Year1Report_12_2009.pdf, 1, 15. This is a report on how college students conduct research, which reported on an online survey that was sent in the fall of 2008 to just under 28,000 students in six higher education institutions in the United States, supported the OCLC report, finding that "Google was the go-to resource for almost all of the students in the sample. Nearly all of the students in the sample reported always using Google, both for courserelated research and everyday life research."

16. Michael Gorman, "Values for Human-to-Human Reference," Library Trends 50, no. 2 (Fall 2001): 171-72, 182

17. Karen Sobel, "Promoting Library Reference Services to First-Year Undergraduate Students: What Works?" Reference \& User Services Quarterly 48, no. 4 (Summer 2009): 362.

18. Rebekah Kilzer, "Reference as Service, Reference as Place: A View of Reference in the Academic Library," Reference Librarian 52, no 4 (Oct.-Dec. 2011) : 291-99.

19. David S. Nolen, "Reforming or Rejecting the Reference Desk: Conflict and Continuity in the Concept of Reference," Library Philosophy and Practice 12, no. 2, (Fall 2010): 1-12.

20. Adeane Bregman and Barbara Mento, "Reference Roving at Boston College," College \& Research Libraries News. 53, no. 10 (November 1992): 634-37; Eileen H. Kramer, "Why Roving Reference: A Case Study in a Small Academic Library," Reference Services Review 24, no. 3 (Fall 1996): 67-80; Terence. K. Huwe, "Casting a Wider Net with Roving Reference," Computers in Libraries 23, no 3 (March 2003): 34-36; Kathryn Robinson, "Point-of-Need Customer Service: Mobile Service Using Wireless Technology," Journal of Access Services 3, no 2 (2005): 1-14; Megan Lotts and Stephanie Graves, "Using the iPad for Reference Services: Librarians Go Mobile," College and Research Libraries News 72, no. 4 (May 2011): 217-20.

21. Sandra Wong and Anne O'Shea, "Librarians Have Left the Building: Ask Use HERE! At Simon Fraser University," Feliciter 50, no. 3 (2004): 90-92; Molly Strothmann and Karen Antell, "The Live-In Librarian: Developing Library Outreach to University Residence Halls," Reference \& User Services Quarterly 50, no. 1 (Fall 2010): 48-58; Triveni Kuchi, Laura Bowering Mullen, and Stephanie Tama-Bartels, "Librarians Without Borders: Reaching Out to Students at a Campus Center," Reference \& User Services Quarterly 43, no. 4 (Summer 2004): 310-17.

22. Crystal D Gale and Betty S. Evans, "Face-to-Face: The Implementation and Analysis of a Research Consultation Service," College and Undergraduate Libraries 14, no 3. (2007): 85-101; Theresa. S. Arndt, "Reference Service Without the Desk," Reference Services Review 38, no. 1 (2010): 71-80

23. Joyce A. Meldrem, Lori A. Mardis, and Carolyn Johnson, "Redesign Your Reference Desk: Get Rid of It!" Currents and Convergence: Navigating the Rivers of Change Proceedings of the Twelfth National Conference of the Association of College and Research Libraries, April 7-10, 2005, ed. Hugh A. Thompson (Chicago, Association of College and Research Libraries, 2005), 305, 307-08.

24. Patricia H. Dawson, "Are Science, Engineering, and Medical Libraries Moving away from the Reference Desk? Results of a Survey of New Jersey Libraries," Science \& Technology Libraries 30 no. 4 (2011) 343-53.

25. Marlys Brunsting, "Reference Staffing: Common Practices of medium-Sized Academic Libraries," Journal of Interlibrary Loan, Document Delivery \& Electronic Reserve 18, no. 2 (2008): 157-58.

26. Steven. J Bell, "Who Needs a Reference Desk?" Library Issues: Briefings for Faculty and Administrators 27, no. 6 (July 2007): 1-4.

27. The 2008 survey revealed 65.82 percent of librarians surveyed indicated that they would never or probably not ever abandon the traditional reference model. The 2009 and 2010 surveys confirmed that still a majority of librarians were holding fast to the traditional model. However, problems with the 2010 survey design made the results unusable. In the 2010 survey, a question was asked the librarians to respond to the statement: Our library is using/will use the following types of reference. A list of several types of reference was given, including email, chat, text messaging, having students at the reference desk, traditional reference (defined as having a librarian at the desk) all hours the library 
is open, and traditional reference some hours that the library is open. The choices they had were we don't want to do this, yes in the distant future ( 5 or more years), yes in the near future (1-4 years), and we are already doing this. The problem occurred when respondents answered the two traditional reference options. Many answered that they were doing both traditional reference all hours that the library was open and some hours that the library was open. Also there were discrepancies with the percentages between the above question and the question that asked how many hours do you offer each type of reference below. Since the percentages were not the same, the survey results were rejected.

28. The Carnegie Foundation for the Advancement of Teaching, The Carnegie Classification of Institutions of Higher Education: About Carnegie Classification, accessed March 9, 2012, http://classifications.carnegiefoundation.org.

29. The Carnegie Foundation for the Advancement of Teaching. The Carnegie Classification of Institutions of Higher Education: Summary Table: Basic Classification, accessed March 9, 2012, http://classifications.carnegiefoundation.org/summary/basic.php; Carnegie Classification Data File, Downloaded January 31, 2011, http:// classifications.carnegiefoundation.org/downloads/public_file/ cc2010_classification_data_file_02.11.2013.xls.

30. The Carnegie Foundation for the Advancement of Teaching, The Carnegie Classification of Institutions of Higher Education: Summary Table: Basic Classification.

31. These comments actually did not come from question 4 but from other questions in the survey. First, third, fourth, and fifth comments came from question 9. The second comment came from question 14. Even though these comments came from questions other than question 4, they seemed to fit at this point in the article. There may be other instances in subsequent questions where the comments quoted actually did not originate from the question being discussed, but they seemed to fit in that part of the discussion.

32. American Library Association, Guidelines for Behavioral Performance of Reference and Information Service Providers, www.ala.org/rusa/ resources/guidelines/guidelinesbehavioral (accessed Jan. 14, 2013).

33. Adeane Bregman and Barbara Mento, "Reference Roving at Boston College," College \& Research Libraries News 53, no. 10 (November 1992): 634-37.

34. Joyce A. Meldrem, Lori A. Mardis, Carolyn Johnson. "Redesign Your Reference Desk: Get Rid of It!" 305, 307-08.

35. Karen Storin Summerhill, "The High Cost of Reference: The Need to Reassess Services and Service Delivery," 79; Theresa. S. Arndt, "Reference Service Without the Desk," 7; Crystal D. Gale and Betty S. Evans, "Face-to-Face: The Implementation and Analysis of a Research Consultation Service," 85-101.

36. William, F. Heinlen, "Using Student Assistants in Academic Reference," RQ15, no. 4 (Summer 1976) 323-25; Gabriela Sonntag and Felicia Palsson, "No Longer the Sacred Cow-No Longer a Desk: Transforming Reference Service to Meet 21st Century User Needs," Library Philosophy and Practice (February 2007), accessed March 8, 2012, www.webpages.uidaho.edu/ mbolin/sonntagpalsson.pdf; Susan M. Ryan, "Reference Transactions Analysis: The Cost-Effectiveness of Staffing a Traditional Academic Reference Desk," Journal of Academic Librarianship 34, no. 5 (September 2008): 389-99; Cheryl. McCain, "Telephone Calls Received at an Academic Library's Reference Desk: A New Analysis," Reference Librarian 47, no. 2 (2007) 5-16; Sarah Barbara Watstein and Steven J. Bell, "Is there a Future for the Reference Desk? A PointCounterpoint Discussion," Reference Librarian 49, no. 1 (2008): 4.

37. American Library Association, Definitions of Reference, 2008, accessed January 14, 2013, www.ala.org/rusa/resources/guidelines/ definitionsofreference. 